\title{
POLA ASUH ORANG TUA TERHADAP ANAK PADA KELUARGA NELAYAN TRADISIONAL DI KELURAHAN MALALAYANG SATU TIMUR KECAMATAN MALALAYANG KOTA MANADO
}

\author{
Avila C. Tuwo1; Lexy K. Rarung2; Djuwita R.R. Aling² \\ 1)Mahasiswa Fakultas Perikanan dan IImu Kelautan Universitas Sam Ratulangi Manado \\ 2)Staff Pengajar Fakultas Perikanan dan IImu Kelautan Universitas Sam Ratulangi Manado \\ Koresponden email : avilatuwo.at @gmail.com
}

\begin{abstract}
This study aims to examine the general situation of traditional fishermen families. In addition, it also examines parental care for children in traditional fishing families in Malalayang Satu Timur Village, Malalayang District, Manado City. The method used in this study is a case study. The population in this study were 64 traditional fishing families in Malalayang Village, East One Environment I and Environment II. Retrieval of data using purposive sampling technique. The samples taken were 30 fishermen families (45\% of the whole population) who had children. The results of the study on parenting for children in traditional fishermen families in Malalayang Satu Timur Village were obtained: Authoritarian parenting patterns, namely $80 \%$ and $60 \%$ of forms of parenting must be submissive and obedient to the wishes of parents, then $10 \%$ and $35 \%$ controls parents to children are very strict, $10 \%$ and $5 \%$ of parents do not compromise with children (1-way communication). The form of permissive parenting is more than half (60\% and $90 \%$ of parents give freedom to children to express their encouragement or desire while $40 \%$ and $10 \%$ never punish children. Forms of democratic parenting that is as much as 40 and $45 \%$ of parents give an explanation of the effects of good and bad deeds, while being responsive to the needs of the child, realistic about the ability of the child and parents being warm and trying to guide the child.

Key Words: parenting, family, fishermen, traditional
\end{abstract}

\begin{abstract}
Abstrak
Penelitian ini bertujuan untuk menelaah keadaan umum keluarga nelayan tradisional di Kelurahan Malalayang Satu Timur Kecamatan Malalayang Kota Manado, Selain itu juga untuk menelaah pola asuh orang tua terhadap anak pada keluarga nelayan tradisional di Kelurahan Malalayang Satu Timur, Kecamatan Malalayang, Kota Manado. Metode yang digunakan dalam penelitian ini adalah studi kasus (case study). Populasi dalam penelitian ini adalah 64 keluarga nelayan tradisional yang ada di Kelurahan Malalayang Satu Timur Lingkungan I dan Lingkungan II. Pengambilan data menggunakan teknik purposive sampling. Sampel yang diambil sebanyak 30 keluarga nelayan ( $45 \%$ dari keselurahan populasi) yang mempunyai anak. Hasil penelitian pada pola asuh orang tua terhadap anak pada keluarga nelayan tradisional di Kelurahan Malalayang Satu Timur didapatkan hasil: Pola asuh otoriter yaitu $80 \%$ dan $60 \%$ bentuk pola asuh anak harus tunduk dan patuh pada kehendak orang tua, selanjutnya $10 \%$ dan $35 \%$ kontrol orang tua terhadap anak sangat ketat, $10 \%$ dan $5 \%$ orang tua tidak kompromi dengan anak (komunikasi 1 arah). Bentuk pola asuh permisif yakni sebanyak lebih dari setengah ( $60 \%$ dan $90 \%$ orang tua memberi kebebasan kepada anak untuk menyatakan dorongan atau keinginannya sedangkan $40 \%$ dan 10\% tidak pernah menghukum anak. Bentuk pola asuh demokratis yakni sebanyak 40 dan $45 \%$ orang tua memberikan penjelasan tentang dampak perbuatan yang baik dan buruk, sedangkan responsif terhadap kebutuhan anak, realistis terhadap kemampuan anak dan orang tua bersikap hangat dan berupaya membimbing anak.
\end{abstract}

Kata Kunci: Rola asuh, Keluarga, Nelayan, Tradisional

\section{PENDAHULUAN}

Masyarakat nelayan merupakan salah satu bagian masyarakat Indonesia yang hidup dengan mengelola potensi sumberdaya perikanan. Sebagai suatu masyarakat yang tinggal di kawasan pesisir, masyarakat nelayan mempunyai karakteristik sosial tersendiri yang berbeda dengan masyarakat yang tinggal di wilayah daratan. Di beberapa kawasan pesisir yang relatif berkembang pesat, struktur masyarakatnya bersifat heterogen, memiliki etos kerja yang tinggi, solidaritas sosial yang kuat terbuka terhadap perubahan dan memiliki karakteristik interaksi sosial yang mendalam. Sekalipun demikian masalah kemiskinan masih menjadi bagian masyarakat pesisir, sehingga fakta sosial ini terkesan ironi di tengah-tengah nelayan yang memiliki hasil kekayaan sumberdaya pesisir dan lautan yang melimpah ruah (Ustman, 2007). 
Kehidupan nelayan relatif keras, karena harus menghadapi tantangan alam dan sosial secara bersamaan. Perjuangan mencari nafkah di lautan berdasarkan perhitungan angin, hujan, yang mana berpadu dengan kekuatan fisik dan otak. Disisi yang lain nelayan harus memperkirakan posisi ikan yang semakin langka karena persaingan dan juga kerusakan ekosistem. Sebagai suatu kesatuan sosial budaya, masyarakat nelayan memiliki ciri-ciri perilaku sosial yang dipengaruhi oleh karakteristik kondisi geografis dan mata pencaharian penduduknya, seperti: kompetitif dan mengandalkan kemampuan diri untuk mencapai keberhasilan, terbuka dan cenderung kasar, meliliki rasa solidaritas yang tinggi, bergaya hidup konsumtif dan temperamental (Kusnadi, 2009).

Usman (2003), mengemukakan bahwa lingkungan alam sekitar akan membentuk sifat dan perilaku masyarakat. Lingkungan fisik dan biologi mempengaruhi interaksi sosial, distribusi peran sosial, karakteristik nilai, norma sosial, sikap serta persepsi yang melembaga dalam masyarakat. Nilai-nilai sosial yang berkembang dari hasil penafsiran atas manfaat dan fungsi lingkungan dapat memacu perubahan sosial.

Secara sosial karakteristik masyarakat nelayan berbeda dengan karakteristik masyarakat petani dalam pengelolaan atau dalam memanfaatkan lahan untuk mencari nafkah. Nelayan menghadapi sumber daya yang tidak terkontrol dimana pada saat hasil tangkapan berkurang, maka nelayan tersebut harus mencari lahan baru. Nelayan bisa bertahan jika didorong semangat hidup yang kuat dengan motto kerja keras agar kehidupan mereka menjadi lebih baik. Ditengah karakteristik sosial masyarakat nelayan yang demikian akan memberi pengaruh pada pola asuh orangtua terhadap anak.
Pola asuh yang diterapkan oleh orang tua kepada anak merupakan dasar awal pembinaan terhadap perkembangan mental anak. Pembinaan dasar yang melekat dalam diri anak akan berpengaruh pada sikap dan perilaku anak. Pola asuh orang tua menurut Kurniawan (2014), adalah pola interaksi antara anak dengan orang tua, yang mencakup pemenuhan kebutuhan fisik (seperti makan, minum dan lain-lain) dan kebutuhan nonfisik (seperti perhatian, empati, kasih sayang dan sebagainya).

Baik atau buruk perilaku seorang anak tergantung dari bagaimana cara orang tua mendidik dan menerapkan pola asuh kepada anaknya. Setiap orang tua memiliki cara dan pola asuh tersendiri dalam mengasuh dan mendidik anak. Cara dan pola asuh tersebut tentu akan berbeda antara satu keluarga dengan keluarga yang lainnya. Kurniawan (2014), menyatakan bahwa pola asuh orang tua terdiri dari tiga bentuk, yaitu: Pertama, pola asuh permisif adalah jenis pola mengasuh anak yang acuh tak acuh terhadap anak. Jadi apa pun yang mau dilakukan anak diperbolehkan, seperti tidak sekolah, bandel, terlibat dalam pergaulan bebas, dan sebagainya. Kedua, pola asuh otoriter adalah pola pengasuhan anak yang bersifat permaksaan, keras, dan kaku dimana orang tua akan membuat berbagai aturan yang harus dipatuhi oleh anak-anaknya tanpa mau tahu perasaan anak. Ketiga, pola asuh demokratis adalah pola asuh orang tua pada anak yang memberikan kebebasan pada anak untuk berkreasi dan mengeksplorasi berbagai hal sesuai dengan kemampuan anak dengan batasan dan pengawasan yang baik dari orang tua.

\section{METODE PENELITIAN}

Jenis penelitian yang digunakan adalah studi kasus (case study), menurut Cresswell (2014), studi kasus adalah sebuah eksplorasi dari suatu sistem yang terikat 
atau suatu kasus/beragam kasus yang dari waktu ke waktu melalui pengumpulan data serta melibatkan berbagai sumber informasi yang kaya dalam suatu konteks. Sistem terikat ini diikat oleh waktu dan tempat, sedangkan kasus dapat dikaji dari suatu program, peristiwa, aktivitas atau suatu individu. Studi kasus merupakan penelitian dimana peneliti menggali suatu fenomena tertentu (kasus) dalam suatu waktu dan kegiatan (program, event, proses, institusi atau kelompok sosial) serta mengumpulkan informasi secara terinci dan mendalam dengan menggunakan berbagai prosedur pengumpulan data selama periode tertentu.

Populasi dalam penelitian ini adalah 64 keluarga nelayan tradisional yang ada di Kelurahan Malalayang Satu Timur, dengan perincian sebagai berikut : Lingkungan I 19 keluarga dan Lingkungan II 45 keluarga. Pengambilan data menggunakan teknik purposive sampling. Purposive sampling adalah teknik penentuan sampel dengan pertimbangan tertentu/sesuai dengan tujuan penelitian (Arikunto, 2002). Sampel yang diambil sebanyak $47 \%$ dari populasi yang ada, yaitu berjumlah 30 responden.

Teknik pengumpulan data primer dilakukan dengan 3 cara yaitu:

\section{Observasi}

Observasi merupakan metode pengumpul data yang dilakukan dengan cara mengamati dan mencatat secara sistematik gejala-gejala yang diselidiki (Supardi, 2006). Melengkapi cara dalam memperoleh data, penulis mempergunakan metode observasi nonpartisan yaitu mengamati mencari data dari berbagai fakta yang ada hubungannya dengan permasalahan. Penyelidikan secara sistematis dan disengaja melalui pengamatan ke arah kejadian-kejadian yang spontan pada saat kejadian terjadi dengan menggunakan alat indera sebagai pengamat (Walgito, 2010).

\section{Wawancara}

Wawancara adalah proses tanya-jawab dalam penelitian yang berlangsung secara lisan di mana dua orang atau lebih bertatap muka mendengarkan secara langsung informasi-informasi atau keteranganketerangan (Supardi, 2006). Sedangkan pendapat ahli lain mengatakan bahwa wawancara adalah percakapan yang dilakukan oleh dua orang atau lebih yaitu wawancara yang akan mengajukan pertanyaan dan orang yang akan diwawancarai yang akan memberikan jawaban atas pertanyaan yang akan diajukan dengan tatap muka maupun telepon. Wawancara yang juga dikenal dengan interview adalah pengumpulan data dengan mengajukan pertanyaan secara langsung oleh pewawancara kepada responden dan jawaban responden dicatat atau direkam (Moleong, 2005).

\section{Kuisioner}

Kuisioner merupakan metode pengumpulan data yang dilakukan dengan cara memberi seperangkat pertanyaan atau pernyataan tertulis kepada responden untuk dijawab. Kuisioner merupakan metode pengumpulan data yang lebih efisien bila peneliti telah mengetahui dengan pasti variabel yang akan diukur dan tahu apa yang diharapkan dari responden.

Analisis data yang digunakan dalam penelitian ini adalah analisis deskriptif kualitatif dan deskriptif kuantitatif. Analisis deskriptif kualitatif yaitu berusaha menggali, memahami pola asuh orang tua nelayan dalam membimbing anak. Penelitian kualitatif dari sisi definisi lainnya dikemukakan bahwa hal itu merupakan penelitian yang memanfaatkan wawancara terbuka untuk menelaah dan memahami sikap, pandangan, perasaan, dan perilaku 
individu atau sekelompok orang (Moleong, 2005). Analisis deskriptif kuantitatif adalah analisis data dengan memberikan bahasan melalui perhitungan-perhitungan statistik sederhana seperti perjumlahan, pengurangan, persentase dan rata-rata.

\section{HASIL DAN PEMBAHASAN}

\section{Tingkat Pendidikan Responden}

Pendidikan merupakan upaya sadar dan terencana untuk mendidik dan mendewasakan manusia, dengan pendidikan dari semula yang tidak tahu menjadi tahu, dari yang tidak paham menjadi paham. Pendidikan dapat diartikan sebagai suatu proses atau kegiatan untuk mengembangkan kepribadian dan kemampuan individu atau masyarakat. Ini berarti bahwa pendidikan adalah suatu pembentukan watak yaitu sikap disertai kemampuan dalam bentuk kecerdasan, pengetahuan dan keterampilan. Menurut (Ihsan, 2005), pendidikan secara sederhana adalah usaha manusia untuk menumbuhkan dan mengembangkan potensi-potensi pembawaan baik jasmani maupun rohani sesuai dengan nilai-nilai yang ada di dalam masyarakat dan kebudayaan. Tingkat pendidikan keluarga nelayan tradisional Kelurahan Malalayang Sata) Timur dapat dilihat pada Tabel 1.

Tabel 1. Tingkat Pendidikan Responden Nelayan di Kelurahan Malalayang Satu Timur

\begin{tabular}{|c|l|c|c|c|c|}
\hline \multirow{2}{*}{ No. } & Pendidikan & \multicolumn{2}{|c|}{ Lingkungan I } & \multicolumn{2}{c|}{ Lingkungan II } \\
\cline { 3 - 6 } & & $\begin{array}{c}\text { Jumlah } \\
\text { (jiwa) }\end{array}$ & Persentase (\%) & $\begin{array}{c}\text { Jumlah } \\
\text { (jiwa) }\end{array}$ & $\begin{array}{c}\text { Persentase } \\
(\%)\end{array}$ \\
\hline 1. & Tamat SD & 2 & 20 & 1 & 5 \\
\hline 2. & Tamat SMP & 5 & 50 & 11 & 55 \\
\hline 3. & Tamat SMA & 3 & 30 & 6 & 30 \\
\hline 4. & Diploma (I/I//II) & - & 0 & 2 & 10 \\
\hline & Jumlah & 10 & 100 & 20 & 100 \\
\hline
\end{tabular}

Sumber : Data Primer diolah, 2019

Berdasarkan Tabel 1 dapat dilihat bahwa tingkat pendidikan respondên yang paling banyak yaitu nelayan yang hanya tamat sampai Sekolah Menengah Pertama (SMP) berjumlah 5 responden $(50 \%)$ di lingkungan I dan 11 responden (55\%) di lingkungan II. Sedangkan nelayan berpendidikan Sekolah Menengah Atas (SMA) berjumlah 3 responden $(30 \%)$ di lingkungan I dan 6 responden $(30 \%)$ di lingkungan II. Selain itu, berpendidikan Sekolah Dasar (SD) berjumlah 2 responden (20\%) di lingkungan I dan 1 responden (5\%) di lingkungan II. Terdapat 2 responden (10\%) nelayan yang ada di lingkungan II, melanjutkan sekolahnya sampai Diploma (I/II/III).

\section{Jumlah Tanggungan Keluarga}

Jumlah tanggungan keluarga merupakan jumlah seluruh orang yang berada dalam satu rumah yang menjadi tanggungan kepala rumah tangga. Hal ini mengingat semakin banyak jumlah anggota keluarga semakin bertambah juga kebutuhan. Peranan dan tingkah laku masyarakat secara keseluruhan merupakan cermin tingkah laku yang berlaku pada suatu keluarga (Kusnadi, 2002). Jumlah tanggungan keluarga yang ada di Kelurahan Malalayang Satu Timur, dapat dilihat pada Tabel 2. 
Tabel 2. Jumlah Tanggungan Keluarga Responden Nelayan Tradisional di Kelurahan Malalayang Satu Timur

\begin{tabular}{|c|c|c|c|c|c|}
\hline \multirow{2}{*}{ No. } & Jumlah Tanggungan & \multicolumn{2}{|c|}{ Lingkungan I } & \multicolumn{2}{|c|}{ Lingkungan II } \\
\cline { 3 - 5 } & & $\begin{array}{c}\text { Jumlah } \\
\text { (Jiwa) }\end{array}$ & Persentase (\%) & $\begin{array}{c}\text { Jumlah } \\
\text { (Jiwa) }\end{array}$ & Persentase (\%) \\
\hline 1. & $1-2$ & - & 0 & 1 & 5 \\
\hline 2. & $3-5$ & 8 & 80 & 13 & 65 \\
\hline 3 & $>5$ & 2 & 20 & 6 & 30 \\
\hline \multicolumn{2}{r|}{ Jumlah } & 10 & 100 & 20 & 100 \\
\hline
\end{tabular}

Sumber: Data Primer diolah, 2019

Berdasarkan Tabel 2 dapat dilihat jumlah anggota keluarga nelayan tradisional di Kelurahan Malalayang Satu Timur Lingkungan I dan Lingkungan II yang paling banyak yaitu 8 responden dengan jumlah anggota keluarga $3-5(80 \%)$ di lingkungan I dan 13 responden $(65 \%)$ di lingkungan II, selanjutnya anggota keluarga $>5$ terdapat 2 responden $(20 \%)$ di lingkungan I dan 6 responden (30\%) di lingkungan II, dan anggota keluarga 1-2 terdapat 1 responden di lingkungan II (5\%).

\section{Pola Asuh Orang Tua Terhadap Anak pada Keluarga Nelayan Tradisional}

Dalam penelitian ini terlihat ada 3 bentuk pola asuh anak pada keluarga nelayan tradisional di Kelurahan Malalayang Satu Timur yaitu: pola asuh otoriter, pola asuh permisif, dan pola asuh demokratis.

\section{Pola Asuh Otoriter}

Pola asuh otoriter yaitu pola asuh di mana orang tua menerapkan aturan dan batasan yang mutlak harus ditaati, tanpa memberi kesempatan pada anak untuk berpendapat, jika anak tidak mematuhi akan diancam dan dihukum. Pola asuh otoriter ini dapat menimbulkan akibat hilangnya kebebasan pada anak, inisiatif dan aktivitasnya menjadi kurang, sehingga anak menjadi tidak percaya diri pada kemampuannya.

Tabel 3. Bentuk Pola Asuh Otoriter

\begin{tabular}{|c|l|c|c|c|c|}
\hline \multirow{2}{*}{ No. } & \multirow{2}{*}{ Bentuk Pola Asuh Otoriter } & \multicolumn{2}{|c|}{ Lingkungan I } & \multicolumn{2}{|c|}{ Lingkungan II } \\
\cline { 3 - 5 } & & $\begin{array}{c}\text { Jumlah } \\
\text { (Jiwa) }\end{array}$ & Persentase (\%) & $\begin{array}{c}\text { Jumlah } \\
\text { (Jiwa) }\end{array}$ & $\begin{array}{c}\text { Persentase } \\
(\%)\end{array}$ \\
\hline 1. & $\begin{array}{l}\text { Anak harus tunduk dan patuh pada kehendak } \\
\text { orang tua }\end{array}$ & 8 & 80 & 12 & 60 \\
\hline 2. & Kontrol orang tua terhadap anak sangat ketat & 1 & 10 & 7 & 35 \\
\hline 3. & Anak hampir tidah pernah menerima pujian & - & 0 & - & 0 \\
\hline 4. & $\begin{array}{l}\text { Orang tua tidak) berkompromi dengan anak } \\
\text { (komunikasi 1 arah) }\end{array}$ & 1 & 10 & 1 & 5 \\
\hline
\end{tabular}

Sumber: Data Rrimer diolah, 2019

Berdasarkan Tabel 3 menjelaskan bahwa bentuk pola asuh otoriter yang ada di Lingkungan I terdapat 8 orang responden $(80 \%)$, di mana dalam hal ini orang tua menghendaki agar anak harus tunduk dan patuh pada kehendak orang tua karena orang tua bertanggung jawab atas kelangsungan hidup dan perkembangan anak. Hal yang berhubungan dengan pola asuh ini, biasanya dilakukan orang tua berpatokan pada iman Kristen dalam Alkitab menyatakan: Hai anak-anak, taatilah orang tuamu di dalam Tuhan, karena haruslah demikian (Efesus 6:1). Pada selanjutnya ada 1 orang responden (10\%) menerapkan pola asuh anak dengan kontrol orang tua terhadap anak sangat ketat. Pada pola asuh ini anak sedikit memperoleh kesempatan untuk mengendalikan perbuatanperbuatannya. Biasanya dilakukan responden ini karena anaknya masih berumur di bawah 17 tahun. Hal-hal seperti 
pulang rumah harus di bawah pukul 22.00 wita, wajib mengaktifkan HP saat berada di luar rumah, memberi tahu orang tua saat bermain di luar rumah. Responden ini berkeyakinan bahwa cara yang keras merupakan cara yang terbaik dalam mendidik anaknya. Adapun orang tua di Lingkungan | dan Lingkungan || tidak berkompromi dengan anak (komunikasi 1 arah) dengan jumlah jiwa yang sama sebanyak 1 jiwa dimana seorang anak diharapkan selalu melaksanakan apapun yang diperintahkan orang tua tanpa membantah maupun memberi pendapat atau masukan.

Bentuk pola asuh otoriter di Lingkungan II terdapat 12 jiwa (60\%) menghendaki anak harus tunduk dan patuh pada kehendak orang tua, selanjutnya bentuk pola asuh otoriter pada kontrol orang tua terhadap anak sangat ketat terdapat 7 jiwa (35\%).

\section{Pola Asuh Permisif}

Permisif berasal dari kata permissive dari kata dalam bahasa Inggris berarti membolehkan dan mengizinkan. Pola asuh permisif dapat diartikan sebagai pola perilaku orang tua dalam berinteraksi dengan anak, yang membebaskan anak untuk melakukan apa yang ingin dilakukan tanpa mempertanyakan. Pola asuh ini tidak menggunakan aturan-aturan yang ketat bahkan bimbinganpun kurang diberikan, sehingga tidak ada pengendalian atau pengontrolan serta tuntutan kepada anak. Kebebasan diberikan penuh dan anak dijijnkan untuk memberi keputusan untuk dirinya sendiri, tanpa pertimbangan orang tua dan berperilaku menurut apa yang diinginkannya tanpa ada kontrol dari orang tua.

Tabel 4. Bentuk Pola Asuh Permisif

\begin{tabular}{|c|l|c|c|c|c|}
\hline No. & \multicolumn{1}{|c|}{$\begin{array}{c}\text { Lingkungan I } \\
\text { Bentuk Pola Asuh Permisif }\end{array}$} & $\begin{array}{c}\text { Lingkungan II } \\
\text { Jumlah } \\
\text { (Jiwa) }\end{array}$ & $\begin{array}{c}\text { Persentase (\%) } \\
\text { Jumlah } \\
\text { (Jiwa) }\end{array}$ & $\begin{array}{c}\text { Persentase } \\
(\%)\end{array}$ \\
\hline 1. & $\begin{array}{l}\text { Orang tua memberikan kebebasan kepada anak } \\
\text { untuk menyatakan dorongan atau keinginannya }\end{array}$ & 6 & 60 & 18 & 90 \\
\hline 2. & Tidak pernah menghukum anak & 4 & 40 & 2 & 10 \\
\hline
\end{tabular}

Sumber: Data Primer diolah, 2019

Berdasarkan Tabel (4) menjelaskan bahwa bentuk pola asuh permisif yang ada di Lingkungan I terdapat 6 jiwa (60\%) orang tua memberikan kebebasan kepada anak untuk menyatakan dorongan keinginan karena orang tua bukannya tidak peduli terhadap tingkah laku serta perilaku anak tetapi hanya tidak ingin adanya konflik terhadap anaknya. Selanjutnya 4 jiwa (40\%) Orang tua tidak pernah menghukum anak karena kondisi anak yang masih di bawah umur. Selain itu, orang tua menyadari bahwa menghukum anak akan memberikan kesan negatif terhadap orang tua hingga mengakibatkan anak menjadi tertekan. Pola asuh permisif akan menghasilkan karakteristik anak yang impulsif, agresif, tidak patuh, manja, kurang mandiri, mau menang sendiri, kurang percaya diri, dan kurang matang secara sosial (Widyarini, 2009).

Bentuk pola asuh permisif di Lingkungan II terdapat 18 jiwa (90\%) orang tua memberikan kebebasan kepada anak untuk menyatakan dorongan atau keinginannya karena orang tua memberikan kepercayaan kepada anak, disamping itu juga orang tua memfokuskan waktu mereka terhadap pekerjaannya masing-masing. Selanjutnya 2 jiwa (10\%) orang tua tidak pernah menghukum anak karena merasa tidak tega untuk menyakiti anak sendiri. 


\section{Pola Asuh Demokratis}

Gunarsa (2000), mengemukakan bahwa dalam menanamkan disiplin kepada anak, orang tua menerapkan pola asuh demokratis memperlihatkan dan menghargai kebebasan yang tidak mutlak, dengan bimbingan yang penuh pengertian antara anak dan orang tua, memberi penjelasan secara rasional dan objektif jika keinginan dan pendapat anak tidak sesuai. Dalam pola asuh ini, anak tumbuh rasa tanggung jawab, mampu bertindak sesuai dengan norma yang ada.

Tabel 5. Bentuk Pola Asuh Demokratis

\begin{tabular}{|c|l|c|c|c|c|}
\hline \multirow{2}{*}{ No. } & \multicolumn{1}{|c|}{ Bentuk Pola Asuh Demokratis } & \multicolumn{2}{|c|}{ Lingkungan I } & \multicolumn{2}{|c|}{ Lingkungan II } \\
\cline { 3 - 6 } & \multicolumn{1}{|c|}{$\begin{array}{c}\text { Jumlah } \\
\text { (Jiwa) }\end{array}$} & $\begin{array}{c}\text { Persentase } \\
(\%)\end{array}$ & $\begin{array}{c}\text { Jumlah } \\
\text { (Jiwa) }\end{array}$ & $\begin{array}{c}\text { Persentase } \\
(\%)\end{array}$ \\
\hline 1. & Responsif terhadap kebutuhan anak & 2 & 20 & 3 & 15 \\
\hline 2. & Realistis terhadap kemampuan anak & 2 & 20 & 3 & 15 \\
\hline 3. & Orang tua bersikap hangat dan berupaya membimbing anak & 2 & 20 & 5 & 25 \\
\hline 4. & $\begin{array}{l}\text { Orang tua memberikan penjelasan tentang dampak perbuatan } \\
\text { yang baik dan buruk }\end{array}$ & 4 & 40 & 9 & 45 \\
\hline \multicolumn{2}{l}{ Jumlah } & 10 & 100 & 20 & 100 \\
\hline
\end{tabular}

Sumber: Data Primer diolah, 2019

Berdasarkan Tabel 5 dapat dijelaskan bahwa pada Lingkungan I, bentuk pola asuh demokratis yang responsif terhadap kebutuhan anak dan realistis terhadap kebutuhan anak, serta orang tua yang bersikap hangat dan berupaya membimbing anak, memiliki jumlah jiwa dan persentase yang sama yaitu 2 jiwa (20\%). Pada bentuk coola asuh orang tua yang responsif terhadap kebutuhan anak dikarenakancorang tua memegang peranan yang penting dalam pertumbuhan dan perkembangan anak. Selanjutnya bentuk perilaku pola asuh yang realistis terhadap kemampuan anak dikarenakan orang tua bersikap sebagai pemberi pendapat dan pertimbangan aktivitas anak. Hal ini mendorong anak untuk mampu berdiri sendiri dan yakin terhadap diri sendiri. Bentuk perilaku pola asuh orang tua yang bersikap hangat dan berupaya membimbing anak dimaksudkan untuk mengajarkan anak memiliki pengendalian diri, berorientasi terhadap prestasi dan mampu bertanggung jawab terhadap kehidupan sosialnya. Selain itu 4 jiwa (40\%), bentuk perilaku pola asuh orang tua yang memberikan penjelasan tentang dampak perbuatan yang baik dan buruk akan membuat anak mampu dalam pengambilan keputusan.

Bentuk pola asuh demokratis di Lingkungan II yang responsif terhadap kebutuhan anak dan realistis terhadap kebutuhan anak, mempunyai jumlah jiwa dan persentase yang sama yaitu 3 jiwa (15\%). Adapun 5 jiwa (25\%) orang tua yang bersikap hangat dan berupaya membimbing anak, serta orang tua yang memberikan penjelasan tentang dampak perbuatan yang baik dan buruk memiliki 9 jiwa $(45 \%)$.

\section{KESIMPULAN}

Berdasarkan hasil dan pembahasan di atas maka dapat disimpulkan bahwa Keadaan penduduk di Kelurahan Malalayang Satu Timur bersifat hetrogen yang terdiri dari berbagai suku dan agama dengan mata pencaharian yang berbeda. Kelurahan Malalayang Satu Timur tersebar pada 9 Kelurahan dan 7 Lingkungan. Penduduk di Kelurahan Malalayang Satu Timur berjumlah 5.863 jiwa terdiri dari pria 2.935 jiwa dan wanita 2.928 jiwa. Nelayan di Kelurahan Malalayang Satu Timur berjumlah 64 orang dan yang ada 
di lingkungan I berjumlah 19 orang dan lingkungan II berjumlah 45 orang. Pada dasarnya keluarga nelayan tradisional memiliki perbedaan dalam keadaan sosial ekonomi. Perbedaan tersebut dapat dilihat pada umur, agama, etnis, tingkat pendidikan, jumlah tanggungan, dan kondisi rumah.

Pola asuh orang tua terhadap anak pada keluarga nelayan tradisional di Kelurahan Malalayang Satu Timur, menerapkan 3 jenis pola asuh yaitu Otoriter, permisif, demokratis. Berdasarkan hasil penelitian dan pembahasan, pola asuh yang dominan dilakukan oleh keluarga nelayan, yaitu pola asuh permisif dengan bentuk pola asuh orang tua yang memberikan kebebasan kepada anak untuk menyatakan dorongan atau keinginannya.

\section{DAFTAR PUSTAKA}

Ahmadi, Abu. 2004. Psikologi Belajar. Rineka Cipta. Jakarta.

Arikunto, S. 2012. Prosedur Penelitian: Suatu Pendekatan Praktek. Rineka Cipta. Jakarta.

Creswell, John, W. 2014. Research Design: Pendekatan Kualitatif. Pustaka Pelajar. Yogyakarta.

Gunarsa, S.D. 2000. Azas Psikologi Keluarga Idaman. BPK Gunung Mulia. Jakarta.

Hauck, Paul. 2003. Psikologi Populer (Mendidik Anak dengan Berhasil). Arcan. Jakarta.

Ihsan, F. 2005. Dasar-dasar Kependidikan. PT. Rineka Cipta. Jakarta.

Kecamatan Malalayang dalam angka 2018 Badan Pusat Statistik Kota Manado.

Kurniawan. 2014. Pengaruh Perhatian Orang Tua. Ar-Ruzz Media.Jakarta.
Kusnadi. 2002. Tekanan Kemiskinan Struktural Komunitas Nelayan Tradisional di Perkotaan. Jurusan Sosiologi FISIP, Universitas Airlangga.

2009. Nelayan: Strategi Adaptasi dan Jaringan Sosial. Humaniora Utama Press. Bandung.

Manurung, M.R. 2005. Manajemen Keluarga. Indonesia Publishing House. Jakarta.

Maryati, Kun dan Juju Suryawati. 2007. Sosiologi Untuk SMA dan MA kelas XII. PT. Glora Aksara: Jakarta.

Moleong, L.J. 2005. Metode Penelitian Kualitatif. Penerbit PT. Remaja Rosdakarya. Bandung.

Mulyadi. 2013. Sistem Akuntansi. Salemba Empat.Jakarta.

Priambodo, Bono Budi. 2013. Ikan Untuk Nelayan. Fakultas Hukum Universitas Indonesia. Jakarta.

Satria, A. 2002. Pengantar Sosiologi Masyarakat Pesisir. Cidesindo. Jakarta.

Supardi, M. D. 2006. Metode Penelitian.Yayasan Cerdas Press.Mataram.

Suprayogo, I. 2001.Metodologi Penelitian Sosial. Rosdakarya, Bandung.

Toha. 2006. Pola Pengasuhan OrangTua. Balai Pustaka.Jakarta.

Undang-Undang Nomor 10 Tahun 1992 Tentang Perkembangan Kependudukan dan Pembangunan Keluarga Sejahtera.

Usman, Husaini. 2003. Metodologi Penelitian Sosial. Bumi Aksara. Jakarta.

Utsman, Sabian. 2007. Anatomi Konflik \& Solidaritas Masyarakat Nelayan: Sebuah Penelitian Sosiologis. Pustaka Pelajar. Yogyakarta.

Walgito, B. 2010. Bimbingan dan Konseling (Studi \&Karir). Penerbit CV. Andi Offset. Yogyakarta.

Yusniyah. 2008. Hubungan Pola Asuh Orang Tua. Jakarta.

Yusuf, Syamsu dan N urihsan, Juntika. 2008. Teori Kepribadian. PT Remaja Rosdakarya. Bandung.

Yusuf, Syamsu. 2006. Psikologi Perkembangan Anak dan Remaja. PT. Remaja Rosdakarya. Bandung. 